\title{
Analisis Ekspor Kopi Indonesia pada Pasar Internasional
}

\author{
Riska Dwi Maulani ${ }^{1}$, Diah Wahyuningsih ${ }^{1^{*}}$ \\ Prodi Ekonomi Pembangunan Fakultas Ekonomi dan Bisnis \\ Universitas Trunojoyo Madura \\ Jl. Raya Telang No 02 Kamal Bangkalan Madura 69162 Jawa Timur \\ *Email: diahwahyuningsih@yahoo.com
}

Naskah diterima 2 Oktober 2020, Revisi 15 Maret 2021, Terbit 29 April 2021

\begin{abstract}
DOI: doi.org/10.21107/pamator.v14i1.8692
Abstract

This study aims to analyze the effect of Gross Domestic Product (GDP), exchange rates, international coffee prices and coffee production on the value of Indonesian coffee exports in the six countries (United States, Germany, Japan, Italy, Malaysia, and the United Kingdom). The data used in this study are secondary data in the form of panel data analysis method is a combination of time series and cross section for the period 20092018. Data processing is done using Stata 14. The results of this study indicate that the real GDP variable has a positive and significant effect on the value of Indonesia's coffee exports in six destination countries. The exchange rate does not significant effect on the value of Indonesian coffee exports in six destination countries international coffee prices have a positive and significant effect on the value of Indonesian coffee exports in six destination countries. Domestic production has a positive and significant effect on the value of Indonesian coffee exports in six countries the value of the dete coefficient rminasi $\left(R^{2}\right)$ is obtained at 0.9474. This means that of the four independent variables namely real GDP, exchange rates, international coffee prices, and production are able to explain the dependent variable namely the value of Indonesian coffee exports of 94.74\% and the remaining $5.26 \%$ explained by other variables.
\end{abstract}

Key words: export value, GDP, exchange rate, international prices, production

\section{PENDAHULUAN}

Era globalisasi membuat suatu negara saling bergantung antara satu sama lain dan tidak dapat berdiri sendiri tanpa adanya hubungan dengan negara-negara lain. Hal ini bertujuan untuk memenuhi kebutuhan barang dan jasa di masing-masing negara tersebut. Seperti halnya kebutuhan manusia yang tidak ada habisnya dan tidak ada batasnya, dimana sumber daya saat ini begitu terbatas dan menjadi permasalahan yang sama di suatu negara. Untuk mengatasi keadaan tersebut maka di era globalisasi ini sangat diperlukan adanya perdagangan internasional. Secara umum proses perdagangan internasional terdiri dari dua kegiatan yaitu ekspor dan impor. Pada dasarnya suatu negara tidak dapat terlepas dari hubungannya dengan negara lain, karena tidak semua kebutuhan dapat dipenuhi di dalam negeri. Setiap negara belum tentu mempunyai faktor-faktor produksi dan iklim yang cocok yang diperlukan untuk produksinya, sehingga negara tersebut melakukan perdagangan internasional dalam kegiatan perekonomiannya. Menurut (Krugman \&
Obstfeld, 2003), ada dua alasan suatu negara melakukan perdagangan yaitu: pertama, setiap negara mempunyai keunggulan komparatif yang berbeda-beda, sehingga dengan melakukan perdagangan akan memperoleh manfaat dari perdagangan yang diterima oleh kedua belah pihak. Kedua, negara yang melakukan perdagangan untuk tujuan mencapai skala ekonomi dalam produksi, artinya dengan melakukan spesialisasi akan semakin efisien sehingga diperoleh skala ekonomi yang lebih besar daripada memproduksi seluruh barang yang dibutuhkan. Dengan adanya spesialisasi diharapkan negara tersebut mempunyai kemampuan memproduksi barang-barang yang dapat bersaing di pasar luar negeri (Sukirno, 2015). Perdagangan internasional menyebabkan nilai tukar khususnya negara berkembang mengalami penurunan. Hal ini disebabkan ekspor masih sangat terbatas pada barang-barang primer, sedangkan komoditas yang diimpor merupakan komoditas dari sektor manufaktur (Nopirin, 1999). 
Kopi asli Indonesia ini memiliki kelebihan dari ragam varietas, kualitas dan rasa yang bervariasi. Keunggulan kopi Indonesia pun sudah diakui oleh dunia. Setiap varietas kopi Indonesia memiliki cita rasa yang khas karena dipengaruhi oleh wilayah tempat kopi ditanam. Iklim tropis di Indonesia, wilayahnya yang luas, banyak pegunungan tinggi dan daerah yang memiliki ketersediaan air yang tinggi menjadi kelebihan Indonesia untuk menanam kopi. Faktor lain yang mempengaruhi rasa adalah kondisi kesuburan tanah, ketersediaan unsur hara, kandungan kimia tanah di Indonesia, faktor geografis dan curah hujan, serta faktor perawatan dari perkebunan kopi yang ada di Indonesia.

Kopi khas Indonesia merupakan komoditas yang mempunyai potensi yang sangat besar untuk bersaing di pasar luar negeri khususnya Eropa, Amerika dan Asia. Potensi ini bisa mendatangkan devisa bagi Indonesia. Berdasarkan hal ini maka perlu dilihat tentang bagaimana potensi dan perkembangan permintaan ekspor kopi Indonesia ke berbagai negara Eropa, Amerika dan Asia. Pada tahun 2018, jumlah ekspor kopi menempati urutan ke empat komoditas terbesar di Indonesia setelah kelapa sawit, karet, dan kelapa. Nilai ekspor kopi mencapai 1,19 milyar US\$. Jumlah tersebut merupakan jumlah biji kopi yang telah di ekspor ke beberapa negara besar di dunia, salah satunya yaitu negara Amerika, Jerman dan negara-negara Eropa. Indonesia menjadi salah satu eksportir kopi terbesar di dunia dan berada pada peringkat keempat. Pada tahun 2018 Indonesia menduduki peringkat keempat sebagi negara pengekspor kopi terbesar di dunia dengan jumlah kopi sebesar 666,000 ton. Angka ini masih terbilang cukup jauh bila dibandingkan dengan negara-negara lain seperti Brazil, Vietnam, dan Colombia. Dan pada tahun 2018 kopi Indonesia mampu menyumbang sekitar $7 \%$ dari kebutuhan kopi dunia.

Berdasarkan Gambar 1, nilai ekspor kopi Indonesia mengalami fluktuasi selama 10 tahun terakhir yaitu mulai tahun 2009-2018. Nilai ekspor kopi yang digunakan adalah dengan satuan US\$. Pada pendeskripsian data penulis menggunakan data 10 tahun yaitu tahun 2009-2018. Data tersebut merupakan data terbaru yang diperoleh dari Badan Pusat Statistik. Data tersebut menunjukkan nilai ekspor kopi Indonesia terbesar adalah negara Amerika Serikat dan nilai ekspor kopi Indonesia terendah adalah negara Inggris. Nilai ekspor suatu komoditas dipengaruhi oleh volume komoditas yang diekspor ke negara tujuan. Perkembangan volume ekspor sendiri dipengaruhi oleh banyaknya permintaan dari negara pengimpor. Hal ini kemudian akan mempengaruhi nilai ekspor sehingga akan menyebabkan pendapatan dari ekspor komoditas kopi tidak stabil karena adanya perubahan permintaan. Kinerja ekspor dapat dinilai dari laju pertumbuhan baik dari sisi nilai maupun volume. Pengembangan ekspor yang berhasil adalah jika laju pertumbuhan ekspor tinggi dan komposisinya tidak didominasi negara tertentu dan produk tertentu.

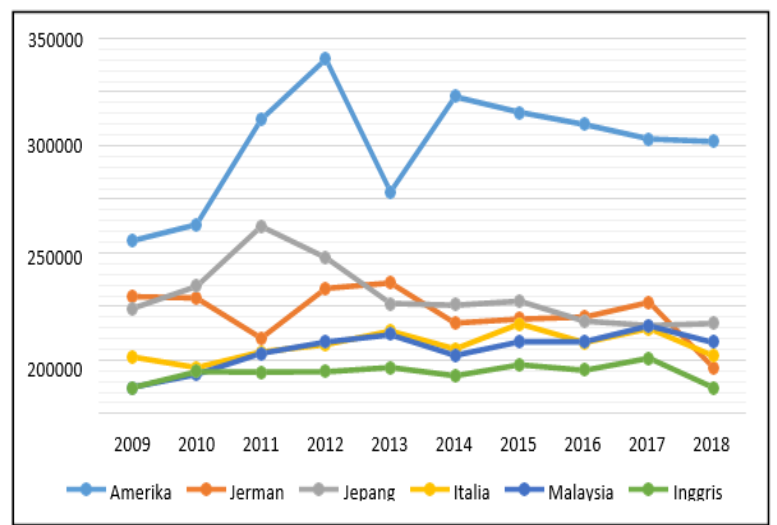

Gambar 1. Nilai Ekspor Kopi Indonesia ke Enam Negara Tujuan Ekspor Kopi Terbesar

Indonesia merupakan salah satu anggota International Coffee Organization (ICO), sebagai anggota ICO maka Indonesia harus mematuhi berbagai peraturan yang ada di ICO. Salah satu peraturan yang sangat penting adalah adanya kuota ekspor yang diberikan untuk para anggotanya. Tujuan peraturan ini cukup mendasar yaitu untuk membatasi jumlah komoditas kopi di pasar internasional yang jika jumlah kopi di pasar internasional terlalu banyak maka harga kopi akan menurun yang berakibat pada ruginya negara eksportir kopi di dunia. Harga kopi dunia sendiri pada tahun 2018 mencapai angka \$1.1360/pound.

Hasil penelitian Ariyadi (2019) menunjukkan meskipun kopi Indonesia termasuk peringkat 4 besar dunia, namun belum memiliki keunggulan komparatif jika dibandingkan dengan ketiga negara lainnya yang disebabkan oleh kualitas kopi itu sendiri. 
Dari segi market share, Jepang merupakan pasar yang cukup potensial bagi pemasaran kopi Indonesia. Market share pada 10 tahun terakhir cenderung stabil sehingga diharapkan berpotensi mengalami peningkatan pada tahun berikutnya. Ekspor kopi Indonesia dan Vietnam di pasar ASEAN 5 memiliki daya saing dengan Indonesia memiliki nilai rata-rata RCA sebesar 10,16 dan Vietnam sebesar 53,44. Hal tersebut menunjukkan bahwa ekspor kopi Vietnam lebih memiliki daya saing jika dibandingkan ekspor kopi Indonesia (Sinta et al., 2017).

Simanjuntak et al. (2017) menganalisis pengaruh produksi, harga internasional dan nilai tukar rupiah terhadap volume ekspor rumput laut Indonesia. Hasil menunjukkan bahwa variabel produksi dan harga internasional tidak berpengaruh signifikan. Sedangkan, variabel nilai tukar rupiah berpengaruh signifikan terhadap volume ekspor rumput laut Indonesia. Sahat et al., (2018) meneliti tentang pengembangan ekspor kopi di Indonesia regresi data panel. Penelitian ini menggunakan alat analisis ekonometrika dengan regresi data panel gravity. Hasil dari penelitian ini menunjukkan bahwa sejak 1994-2013, ekspor Indonesia didominasi oleh komoditas (kacang hijau). Ekspor dalam bentuk komoditas sangat lemah terkait dengan fluktuasi harga di pasar internasional. Hal ini menyebabkan rekomendasi kopi olahan yang lebih tinggi yang tergabung dalam struktur ekspor kopi Indonesia. Pada saat yang sama, mengenai karakteristik produk, diversifikasi produk kopi Indonesia dari kacang hijau ke ekstrak kopi sejalan dengan negara tujuan.

Chandra et al., (2013) menganalisis tentang prospek perdagangan kopi robusta Indonesia di pasar internasional. Hasil penelitian menunjukkan bahwa diperkirakan dalam 10 tahun ke depan, dari 2012 hingga 2021, volume ekspor kopi Indonesia akan meningkat. Pertumbuhan volume ekspor kopi robusta akan menjadi 1,6\% setiap tahun. Akhirnya, pada 2021 volume ekspor kopi robusta akan mencapai 493.295 ton. Penelitian Reyndi et al., (2018) menemukan bahwa rata-rata perkembangan ekspor kopi Indonesia ke Amerika Serikat adalah sebesar $12,33 \%$ pertahun. Harga kopi mengalami perkembangan dengan rata-rata sebesar $8,81 \%$, produksi kopi mengalami perkembangan rata- rata sebesar $2,11 \%$,
Produk Domestik Bruto (PDB) Amerika Serikat mengalami perkembangan rata-rata sebesar $2,94 \%$ dan nilai tukar rupiah mengalami perkembangan rata-rata sebesar $2,80 \%$;

Dalam perdagangan internasional komoditas kopi, daya saing kopi Indonesia menjadi sangat penting. Masih rendahnya pangsa ekspor kopi Indonesia jika dibandingkan dua negara kompetitor lain seperti Brazil, dan Vietnam masih menjadi hambatan yang cukup berarti dalam upaya meningkatkan kinerja ekspor kopi Indonesia walaupun jika dibandingkan dengan Colombia, Indonesia masih sedikit lebih unggul. Tujuan penelitian (1) Menganalisis pengaruh GDP terhadap nilai ekspor kopi Indonesia, (2) Menganalisis pengaruh nilai tukar terhadap nilai ekspor kopi Indonesia, (3) Menganalisis pengaruh harga kopi internasional terhadap nilai ekspor kopi Indonesia, (4) Menganalisis pengaruh produksi terhadap nilai ekspor kopi Indonesia.

\section{METODOLOGI \\ Jenis dan Sumber Data}

Penelitian ini menggunakan pendekatan kuantitatif digunakan untuk melihat bagaimana pengaruh Gross Domestic Product (GDP), kurs, harga kopi internasional, dan produksi terhadap nilai ekspor kopi Indonesia. Obyek penelitian ini adalah 6 negara tujuan ekspor kopi terbesar dari Indonesia yaitu Amerika Serikat, Jerman, Jepang, Italia, Malaysia, dan Inggris. Data yang digunakan adalah nilai ekspor kopi Indonesia, GDP rill negara pengimpor, nilai tukar, harga kopi internasional, dan jumlah produksi kopi dalam negeri. Adapun data yang digunakan di dalam penelitian ini adalah data sekunder yang diperoleh dari beberapa instansi seperti website Badan Pusat Statistik (BPS), World Bank, dan International Coffee Organization (ICO).

\section{Definisi Operasional Variabel}

Definisi operasional dari variabel yang digunakan dalam penelitian ini adalah:

1. Nilai ekspor kopi Indonesia yang dinyatakan dalam satuan US\$.

2. GDP Riil negara Amerika, Jerman, Jepang, Italia, Malaysia, dan Inggris yang dinyatakan dalam satuan US\$.

3. Nilai Tukar menggunakan kurs negara 
Amerika Serikat, Jerman, Jepang, Italia, Malaysia, dan Inggris terhadap mata uang rupiah kemudian dikonversikan ke dalam mata uang yang digunakan dalam transaksi perdagangan internasional yaitu US\$.

4. Harga Kopi Internasional menggunakan data harga kopi internasional dan diperdagangkan di pasar global pada setiap tahunnya yang dinyatakan dalam satuan US\$.

5. Produksi Kopi Indonesia menggunakan data jumlah produksi kopi Indonesia selama kurun waktu 10 tahun yaitu tahun 2009-2018 yang dinyatakan dalam satuan ton.

\section{Hipotesis}

Berdasarkan tinjauan kajian teori yang ada, serta uraian pada penelitian terdahulu maka penulis mencoba untuk merumuskan hipotesis yang akan diuji kebenarannya. Hipotesis penelitian ini adalah:

1. Diduga GDP berpengaruh positif dan signifikan terhadap nilai ekspor kopi Indonesia.

2. Diduga kurs/nilai tukar berpengaruh negatif dan signifikan terhadap nilai ekspor kopi Indonesia.

3. Diduga harga kopi dunia berpengaruh positif dan signifikan terhadap nilai ekspor kopi Indonesia.

4. Diduga produksi kopi berpengaruh positif dan signifikan terhadap nilai ekspor kopi Indonesia.

\section{Metode Analisis}

Data panel merupakan gabungan antara data lintas waktu (time series) dan data silang (cross section). Analisi data panel digunakan untuk mengamati hubungan antara satu variabel tak bebas dengan satu atau lebih variabel bebas. Penggunaan data panel memiliki beberapa keunggulan secara statistik maupun secara teori ekonomi Gujarati \& Porter (2010), yaitu antara lain:

1. Teknik estimasi menggunakan data panel akan menghasilkan keanekaragaman secara tegas dalam perhitungan dengan melibatkan variabel- variabel individu secara spesifik.

2. Memberikan informasi lebih banyak, variabilitas yang lebih baik, mengurangi hubungan antara variabel bebas, memberikan lebih banyak derajat kebebasan, dan lebih efisien.

3. Data panel dapat mendeteksi dan mengukur efek yang tidak dapat dilakukan oleh data time series maupun cross section.

4. Data panel memungkinkan peneliti untuk mempelajari medel perilaku yang lebih kompleks.

5. Data panel dapat meminimalkan bias.

Metode analisis regresi data panel dapat dilakukan dengan 3 pendekatan, yaitu sebagai berikut:

1. Common Effect Model atau Pooled Least Square (PLS)

Sistematika common effect model adalah penggabungan dua data yaitu time series dan cross section ke dalam data panel. Dari data tersebut akan diregresi dengan metode OLS (Oridinary Least Square), dengan dilakukan regresi semacam ini maka tidak dapat mengetahui perbedaan baik antar individu maupun antar waktu disebabkan karena pendekatan yang digunakan mengabaikan dimensi individu maupun rentan waktu yang mungkin saja berpengaruh. Adanya perbedaan intersep dan slope diasumsikan serta dijelaskan oleh error variable atau residual.

2. Fixed Effect Model

Pendugaan parameter regresi data panel dengan fixed effect model dapat menggunakan teknik penambahan dummy variable ataupun tidak. Fixed effect model diasumsikan bahwa koefisien slope bernilai riil tetapi intersep bersifat tidak riil. Model estimasi ini juga disebut dengan Least Squares Dummy Variables (LSDV).

3. Random Effect Model

Sebagaimana yang telah diketahui bahwa pada model efek tetap mempunyai perbedaan karakteristik individu dan waktu diakomodasikan pada intersep sehingga intersep akan berubah antar waktu. Sementara random effect model mempunyai karakteristik individu dan waktu diakomodasikan pada error dari model. Mengingat ada dua komponen waktu dan error gabungan. Model ini juga disebut dengan Error Component Model 
(ECM) atau teknik Generalized Least Square (GLS).

Dalam penelitian ini persamaan model yang digunakan ditunjukkan oleh persamaan berikut :

\begin{tabular}{|c|c|}
\hline \multicolumn{2}{|c|}{$\begin{array}{c}\text { Nekspor }_{i t}=\beta 0+\beta 1\left(\mathrm{GDP}_{i t}\right)+\beta 2\left(\mathrm{Kurs}_{\mathrm{it}}\right)+ \\
\beta 3\left(\mathrm{HKI}_{\mathrm{it}}\right)+\beta 4\left(\text { Produksi }_{i t}\right)+\varepsilon_{\mathrm{t}} \ldots \ldots . .\end{array}$} \\
\hline Nekspor ${ }_{i t}$ & $\begin{array}{l}\text { Nilai ekspor kopi ke negara i pada } \\
\text { tahun } t\end{array}$ \\
\hline$\beta 0$ & Konstanta \\
\hline $\mathrm{GDP}_{\text {it }}$ & $\begin{array}{l}\text { Real Gross Domestic Product } \\
\text { negara i pada tahun t }\end{array}$ \\
\hline Kurs $_{\text {it }}$ & $\begin{array}{l}\text { Nilai tukar negara i terhadap USD } \\
\text { pada tahun } t\end{array}$ \\
\hline $\mathrm{HKI}_{\text {it }}$ & $\begin{array}{l}\text { : Harga kopi internasional pada } \\
\text { tahun t }\end{array}$ \\
\hline Produksi $_{i t}$ & : Produksi kopi negara i pada tahun \\
\hline$\varepsilon t$ & Residual (error term) \\
\hline
\end{tabular}

\section{HASIL PEMBAHASAN}

Penentuan metode estimasi dilakukan untuk menentukan model terbaik yang akan digunakan dalam penelitian ini. Uji Chow dilakukan untuk memilih salah satu model pada regresi data panel, yaitu common effect model dan fixed effect model. Berdasarkan hasil uji spesifikasi model dengan mengunakan uji chow dapat diketahui bahwa nilai probabilitas dari Cross Section $>\mathrm{F}$ diperoleh sebar 0.0026. Nilai tersebut kurang dari taraf signifikansi 0.05 artinya $\mathrm{HO}$ ditolak dan $\mathrm{H} 1$ diterima, sehingga model terbaik yang dapat digunakan adalah Fixed Effect Model (FEM). Untuk selanjutnya diperlukan untuk melakukan uji hausman yang bertujuan untuk memilih model yang terbaik antara fixed effect model atau random effect model. Tabel 1. Hasil Analisis Regresi Data Panel

\begin{tabular}{|c|c|c|}
\hline Variabel & Coefficient & Prob. \\
\hline C & -127939.2 & $0.007^{\star}$ \\
\hline GDP & $1.35 \mathrm{E}-08$ & $0.000^{*}$ \\
\hline Kurs & -202282.5 & 0.942 \\
\hline HKI & 45919.13 & $0.000^{*}$ \\
\hline Produksi & 137.677 & $0.002^{*}$ \\
\hline
\end{tabular}

Keterangan: ${ }^{*}$ Signifikan pada $\alpha=1 \%$

Berdasarkan persamaan regresi di atas, dapat dilihat bahwa nilai konstanta sebesar 127939.2, artinya bahwa apabila variabelvariabel yang digunakan dalam penelitian ini 0 , maka tidak dapat melakukan kegiatan ekspor karena tidak adanya kegiatan produksi.

\section{Pengaruh GDP (Gross Domestic Product) terhadap Nilai Ekspor Kopi}

Variabel GDP berpengaruh positi dan signifikan terhadap nilai ekspor kopi Indonesia dengan koefisien sebesar 1.35E08 . Artinya ketika GDP riil naik US\$ 1 maka nilai ekspor kopi akan naik sebesar 1.35E- 08 US\$, dengan asumsi variabel lain tetap. Begitu pula sebaliknya, jika GDP riil turun 1 US\$ maka nilai ekspor akan turun sebesar 11.35E-08 US\$. Penjelasan diatas menunjukkan bahwa hasil dari penelitian ini sesuai dengan hipotesis yang telah dijelakan, bahwa GDP berpengaruh positif dan signifikan terhadap nilai ekspor kopi Indonesia. Mankiw (2016) mengemukakan bahwa jika GDP perkapita riil suatu negara tinggi, maka negara tersebut memiliki kemampuan yang tinggi untuk melakukan pembelian sehingga merupakan pasar yang potensial bagi pemasaran suatu komoditi. Hal ini tentu akan meningkatkan kemampuan negara pengimpor untuk membeli kopi dari Indonesia dengan jumlah yang lebih banyak, sehingga dapat meningkatkan volume dan nilai ekspor kopi Indonesia. Hasil dari penelitian ini sejalan dengan penelitian Ginting \& Kartiasih (2019) dan Ariyadi (2019) menyatakan bahwa pendapatan domestik di negara tujuan ekspor berpengaruh positif terhadap ekspor suatu negara. Dimana semakin besar GDP yang dihasilkan oleh suatu negara akan semakin bertambah kemampuan negara tersebut untuk melakukan perdagangan.

\section{Pengaruh Kurs terhadap Nilai Ekspor Kopi}

Variabel kurs tidak berpengaruh terhadap nilai ekspor kopi Indonesia. Hal tersebut tidak sesuai dengan hipotesis karena nilai mata uang negara tujuan ekspor kopi Indonesia lebih tinggi dari nilai mata uang rupiah itu sendiri. Tidak adanya pengaruh yang signifikan antara nilai kurs dengan nilai ekspor kopi juga disebabkan semakin tingginya permintaan pasar terhadap komoditas tersebut, sehingga ketika kurs rupiah mengalami depresiasi maupun apresiasi maka tidak terlalu berpengaruh terhadap jumlah permintaan kopi karena kopi telah menjadi komoditas yang paling dicari di 
seluruh penjuru dunia meskipun harganya menjadi relatif lebih mahal. Sejalan dengan penelitian Carolina \& Aminata (2019) dan Ariyadi (2019) yang menyatakan bahwa kurs rupiah tidak berpengaruh signifikan terhadap volume maupun nilai ekspor kopi karena tingginya kebutuhan dan permintaan dari negara tujuan ekspor. Selain itu perubahan nilai kurs rupiah juga dianggap tidak terlalu membawa dampak yang berarti bagi harga kopi karena nilai kurs negara- negara pengimpor yang lebih tinggi.

\section{Pengaruh Harga Kopi Internasional terhadap Nilai Ekspor Kopi}

Variabel harga kopi internasional berpengaruh positif dan signifikan terhadap nilai ekspor kopi deng koefisien sebesar 45919.13. Artinya ketika harga kopi internasional naik US\$ 1 maka nilai ekspor kopi akan naik sebesar 45919.13 US\$, dengan asumsi variabel lain tetap. Begitu pula sebaliknya, jika harga kopi internasional turun 1 US\$ maka nilai ekspor akan turun sebesar 45919.13 US\$. Penjelasan diatas menunjukkan penelitian ini sesuai dengan hipotesis yang telah dijelaskan, bahwa harga kopi internasional berpengaruh positif dan signifikan terhadap nilai ekspor kopi Indonesia. Soekartawi (2005) menjelaskan bahwa hubungan harga internasional dengan volume ekspor adalah jika harga komoditas di pasar global lebih besar daripada di pasar domestik, maka umlah komoditas yang diekspor semakin banyak sehingga baik volume maupun nilai ekspor dari suatu komoditas akan meningkat. Hal ini sejalan dengan penelitian yang dilakukan oleh Nanda (2019) yang menyatakan bahwa harga kopi internasional berpengaruh positif dan signifikan terhadap nilai ekspor kopi Indonesia. Semakin tinggi harga suatu komoditas maka jumlah yang ditawarkan oleh penjual semakin meningkat.

\section{Pengaruh Jumlah Produksi terhadap Nilai Ekspor Kopi}

Variabel produksi berpengaruh positif dan signifikan terhadap nilai ekspor kopi Indonesia dengan koefisien sebesar 137.677. Artinya ketika jumlah produksi naik 1 ton maka nilai ekspor kopi akan naik sebesar 137.677 US\$, dengan asumsi variabel lain tetap. Begitu pula sebaliknya, jika jumlah produksi turun 1 ton maka nilai ekspor akan turun sebesar 137.677 US\$. Penjelasan diatas menunjukkan bahwa hasil dari penelitian ini sesuai dengan hipotesis yang telah dijelaskan, bahwa jumlah produksi berpengaruh positif dan signifikan terhadap nilai ekspor kopi Indonesia. Komalasari (2008) menyatakan produksi yang meningkat akan berpengaruh positif terhadap penawaran ekspor. Saat produksi kopi Indonesia meningkat, maka volume ekspor kopi Indonesia akan meningkat karena penawaran meningkat dan begitu juga sebaliknya. Meningkatnya volume ekspor kopi akan meningkatkan nilai ekspor dari komoditas tersebut. Hasil penelitian ini sama halnya dengan penelitian Marbun (2015) yang menyatakan bahwa jumlah produksi suatu komoditas berpengaruh positif dan signifikan terhadap volume dan nilai ekspor. Kelebihan produksi akan mendorong suatu negara untuk mengekspor karena telah mampu memenuhi kebutuhan dalam negeri sehingga sisanya akan dijual ke luar negeri.

\section{KESIMPULAN}

Berdasarkan hasil penelitian dan analisis yang telah diuraikan, maka dapat ditarik kesimpulan yakni sebagai berikut :

1. Ekspor kopi Indonesia masih didominasi biji kopi yang harganya sangat tidak stabil dan mudah diguncang situasi pasar, Biji kopi yang dihasilkan Indonesia didominasi jenis robusta yang dianggap kopi kelas dua di pasar internasional. Hal ini menyebabkan fluktuasi nilai ekspor tidak terkendali dan sangat mempengaruhi kinerja ekspor kopi Indonesia.

2. Ekspor kopi ke enam negara tujuan ekspor terbesar (Amerika Serikat, Jerman, Jepang, Italia, Malaysia, dan Inggris) selama 10 tahun terakhir yaitu dari tahun 2009-2018 cenderung berfluktuatif dan mengalami penurunan yang cukup signifikan di tahun 2018 baik volume maupun nilai ekspornya.

3. Gross Domestic Product (GDP) negara pengimpor, harga kopi internasional, dan produksi dalam negeri berpengaruh positif atau dapat meningkatkan baik volume maupun nilai ekspor kopi Indonesia.

4. Sedangkan untuk kurs tidak berpengaruh secara signifikan terhadap volume maupun nilai ekspor kopi Indonesia. 


\section{DAFTAR PUSTAKA}

Ariyadi, M. Y. (2019). Analisis pengaruh GDP riil, kurs dan harga udang terhadap volume ekspor udang di Indonesia menurut negara tujuan tahun 2011-2017 [UPN "Veteran" Yogyakarta]. In PhD Thesis.

https://doi.org/10.1017/CBO97811074153 24.004

Carolina, L. T., \& Aminata, J. (2019). Analisis daya saing dan faktor yang mempengaruhi ekspor batu bara. Diponegoro Journal of Economics, 1(1), 9-21.

Chandra, D., Ismono, R. H. dan, \& Kasymir, E. (2013). Prospek perdagangan kopi robusta Indonesia di pasar internasional. Jurnal IImu IImu Agribisnis, 1(1), 10-15.

Ginting, C. P., \& Kartiasih, F. (2019). Analisis ekspor kopi Indonesia ke negara- negara ASEAN. Jurnal IImiah Ekonomi Dan Bisnis, 16(2), 143-157. https://doi.org/10.31849/jieb.v16i2.2922

Gujarati, D. N., \& Porter, D. C. (2010). Basic Econometrica (5th ed.). Mc Graw Hill.

Komalasari, A. (2008). Analisis tentang pelaksanaan plant layout dalam usaha meningkatkan efisiensi produksi. Universitas Widyatama.

Krugman, P., \& Obstfeld, M. (2003). International Economics: Theory and Policy (Sixth Ed). Elm Street Publishing Services, https://doi.org/10.4324/9780203462041

Mankiw, N. G. (2016). Principles of economics (8th ed.). Cengage Learning.

Marbun, L. (2015). Pengaruh produksi, kurs, dan gross domestic product (GDP) terhadap ekspor kayu lapis. Economics Development Analysis Journal, 4(2), 129136.

https://doi.org/10.15294/edaj.v4i2.14812

Nanda, Z. (2019). Analisis pengaruh PDB Indonesia, harga kopi dunia , dan nilai tukar USD - rupiah terhadap volume ekspor kopi Indonesia tahun 1985 - 2017. In Skripsi. Universitas Islam Negeri Syarif Hidayatullah.

Nopirin. (1999). Ekonomi internasional (3rd ed.). BPFE.

Simanjuntak, P. T. H., Arifin, Z., \& Mawardi, M. K. (2017). Pengaruh produksi, harga internasional dan nilai tukar rupiah terhadap volume ekspor rumput laut Indonesia (studi pada tahun 2009 - 2014). Journal of Business Administration, 50(3), 163-171.

administrasibisnis.studentjournal.ub.ac.id

Sinta, N. M., Alamsyah, Z., \& Elwamendri. (2017). Analisis daya saing ekspor kopi Indonesia dan Vietnam di pasar ASEAN. Jurnal IImiah Sosio Ekonomika Bisnis, 20(1), 1-11.

Soekartawi. (2005). Agribisnis: Teori dan aplikasinya (8th ed.). Raja Grafindo Persada.

Sukirno, S. (2015). Makroekonomi: Teori pengantar (3rd ed.). RajaGrafindo Persada. 